\title{
The importance of website quality to brand loyalty: The case study of beauty salons in Vietnam
}

\author{
Van Nam Mai ${ }^{\mathrm{a}}$ and Quoc Nghi Nguyen ${ }^{\mathrm{a}^{*}}$
}

${ }^{a}$ Can Tho University, Vietnam

\section{H R O N I C L E}

Article history:

Received: April 15, 2021

Received in revised format: June

28,2021

Accepted: July 5, 2021

Available online: July 5, 2021

Keywords:

Website quality

Brand impression

Perceived quality

Brand loyalty

Beauty salon

\begin{abstract}
A B S T R A C T
Website quality is an important factor, positively affecting brand impression and perceived quality, thereby promoting brand loyalty. The study was conducted to indicate the relationship between website quality, perceived quality, brand impression, and brand loyalty of customers towards beauty salons in Vietnam. Research data were collected using a quota sampling with 300 customers who have used salon services. By applying the structural equation modeling (SEM), the study showed that the website quality of beauty salons has a positive impact on the brand's impression and perceived quality of customers. Besides, the brand impression positively influences the perceived quality of customers and improves brand loyalty to beauty salons.
\end{abstract}

\section{Background}

Information technology plays an important role in transforming from traditional commerce to e-commerce (Collins \& Cobanoglu, 2013; Wang et al., 2015). The rapid development of information technology and especially, the internet has created a dynamic and fair competitive environment for the enterprise community. The internet plays a crucial role in business operations. E-service quality reflected by website quality is a key tool in the business strategies of organizations. Website quality is important in enhancing customers' purchase intention online (Baggozi and Dholakia, 2006). Website quality is an essential factor affecting customer's perceived quality about services (Ahn et al., 2004; Hsu et al., 2007). Also, the website quality of an organization impacts a certain number of potential customers (Winter et al., 2003). If the business owner focuses on improving the quality of the website, it will put a positive impression and help increase customer trust in the organizational brand (Braddy et al., 2008; Everard \& Galletta, 2005). Therefore, the website quality has contributed to improving the brand loyalty of customers (Baggozi et al., 1999; Chaudhuri \& Holbrook, 2001; Jeon \& Jeong, 2017). For beauty services, brand impression and perceived quality are always paid attention by customers. Thus, beauty salons in Vietnam are greatly interested in investing and upgrading the website quality to create a positive brand impression and retain customers. This study was carried out to prove the relationship between website quality, brand impression, perceived quality, and brand loyalty of customers towards beauty salons in Vietnam.

* Corresponding author.

E-mail address: quocnghi@ctu.edu.vn (Q. N. Nguyen)

(C) 2021 by the authors; licensee Growing Science, Canada. doi: $10.5267 /$ j.ijdns.2021.7.003 


\section{Theoretical Framework and Research Hypotheses}

\subsection{Theoretical framework}

\section{Website quality (WEBQUAL)}

Website quality demonstrates the ability of a website that allows users to accomplish their goals (Loiacono et al., 2002). According to Carlson (2003), the quality of a website is not only limited to the service quality of that website but also plenty of other aspects such as system structure, information quality, security, etc. Website quality is the quality of services provided by that website system (Li \& Jiao, 2008). Website quality is measured by different criteria, the most common criteria used by many researchers are design characteristics (Kaynama \& Black, 2000; Aladwani \& Palvia, 2002; Loiacono et al., 2002; Kim, 2005; Yang et al., 2005; Nusair \& Kandampully, 2008), information quality (Kaynama \& Black, 2000; Jeong \& Lambert, 2001; Aladwani \& Palvia, 2002; Loiacono et al., 2002; Kim, 2005; Yang et al., 2005; Ho \& Lee, 2007; Chaiprasit et al., 2011), accessibility (Kaynama \& Black, 2000; Cox \& Dale, 2001; Jeong \& Lambert, 2001; Geissler, 2001; Madu \& Madu, 2002; Yang et al., 2005), safety (Aladwani \& Palvia, 2002; Loiacono et al., 2002; Yang et al., 2005; Ho \& Lee, 2007; Chaiprasit et al., 2011), convenience (Kaynama \& Black, 2000; Loiacono et al., 2002; Kaynama \& Black, 2000; Kim, 2005; Yang et al., 2005; Ho \& Lee, 2007; Chaiprasit et al., 2011; Mohamed \& Moradi, 2011), personalization (Madu \& Madu, 2002, Kim \& Lee, 2004, Yang et al., 2005; Ho \& Lee, 2007), and innovation (Yoo \& Donthu, 2000; Loiacono et al., 2002; Madu \& Madu, 2002).

\section{Brand impression}

A brand impression is a perception of a brand reflected by the brand associations in the minds of customers (Newman, 1975). A brand impression is the representation of the brand in customers' minds (Dobni \& Zinkhan, 1990) and the feelings that customers feel about a brand (Keller, 1993). An organization or a product/service that continually keeps a good image in the minds of customers will surely achieve a better position in the market, improve its competitive advantage, and win more market share (Park et al., 1986). According to Hsieh et al. (2004), successfully building a brand impression will motivate customers to generate demands and distinguish them from the demands for products of competitors.

\section{Perceived quality}

According to Dawar (1996), perceived quality is the perception or overall evaluation of customers about the superiority and excellence of a product/service. Perceived quality is a subjective judgment of customers about a product/service (Zeithaml, 1988; Dodds et al., 1991). As reported by Aaker (1991), perceived quality shows the remarkable difference of a product/service that may become a brand in the minds of customers. Perceived quality is measured by factors such as previous experience, educational background, risk perception, and purchase situation (Holbrook \& Corfman, 1985).

\section{Brand loyalty}

Brand loyalty is the engagement of customers to a brand (Aaker, 1991). Brand loyalty is an interest of a brand that customers will not consider other brands when they have a product demand (Baldinger \& Rubinson, 1996; Brújula \& Calvo, 1997). Loyalty is created when customers commit to a brand (Kim et al., 2008), in which they intend to use the brand in the future (Oliver, 1999), recommend the brand to others, and ignore negative information about that brand (Sutikno, 2011).

\subsection{Research Hypotheses}

\section{The relationship between website quality and brand impression}

According to Winter et al. (2003), website quality affects potential customers' brand impressions. The website attributes such as information quality, site aesthetics, processing speed, privacy, etc. create a brand impression in the minds of customers (Karimov et al., 2011). Website quality significantly influences brand impression and customer trust (Everard \& Galletta, 2005; Braddy et al., 2008). Therefore, hypothesis H1 is proposed as follows:

$\mathbf{H}_{1}$ : Website quality positively affects customers' brand impression on beauty salons.

The relationship between website quality and perceived value

Website quality is a key factor playing a decisive role in improving customer satisfaction and perception (Madu \& Madu, 2002; Kim \& Lee, 2005). According to Moon \& Kim (2001), the perceived quality of a customer for a website affects his or her attitude and behavioral intentions. Website quality positively affects the perceived quality of customers, motivating them to interact with the website (Ahn et al., 2004; Hsu et al., 2007). Hence, the hypothesis H2 is proposed as follows:

$\mathbf{H}_{2}$ : Website quality positively impacts customers' perceived quality for beauty salons.

\section{The relationship between brand impression and perceived quality}

Customer perceptions of a product/service quality are significantly influenced by their brand impressions (Szybillo \& Jacoby, 1974; Shimp \& Bearden, 1982; Rao \& Monroe, 1989). Besides, Kotler \& Armstrong (2010) used the brand impression to evaluate the quality of products/services. Richardson et al. (1994) showed a positive relationship between brand impression and perceived quality. Thus, the study stated hypothesis H3: 
Table 1

Interpretation of observed variables in the research model

\begin{tabular}{|c|c|c|c|}
\hline Factor & Observed variables & Scale & Reference resources \\
\hline \multirow{3}{*}{ Site aesthetic (SA) } & $\begin{array}{l}\text { SA1: Website of the beauty salon }(\mathrm{X}) \text { uses a readable font and color } \\
\text { combination. }\end{array}$ & Likert $1-5$ & \multirow{3}{*}{$\begin{array}{l}\text { Kaynama \& Black (2000), } \\
\text { Yoo \& Donthu (2000), } \\
\text { Aladwani \& Palvia (2002) }\end{array}$} \\
\hline & SA2: Website of the beauty salon $(\mathrm{X})$ uses an interesting visual design. & Likert $1-5$ & \\
\hline & SA3: Website of the beauty salon (X) is creative and professional. & Likert $1-5$ & \\
\hline \multirow{3}{*}{$\begin{array}{l}\text { Information } \\
\text { quality (IQ) }\end{array}$} & IQ1: The information posted on the (X) salon's website is helpful. & Likert $1-5$ & \multirow{3}{*}{$\begin{array}{l}\text { Ho \& Lee, (2007), Kim \& } \\
\text { Lee (2004), Kaynama \& } \\
\text { Black (2000), Yang et al. } \\
(2005) .\end{array}$} \\
\hline & IQ2: The salon (X)'s website provides adequate information about services. & Likert $1-5$ & \\
\hline & IQ3: The salon (X)'s website updates reliable information continuously. & Likert $1-5$ & \\
\hline \multirow{3}{*}{$\begin{array}{l}\text { Convenience } \\
\quad(\mathrm{CON})\end{array}$} & CON1: Website of the beauty salon $(\mathrm{X})$ has easy navigation. & Likert $1-5$ & \multirow{3}{*}{$\begin{array}{l}\text { Yang \& Jun (2002), Kim } \\
\& \text { Lee (2004), Ho \& Lee } \\
(2007) .\end{array}$} \\
\hline & $\begin{array}{l}\text { CON2: The search function on the beauty salon (X)'s website is easy to } \\
\text { understand and use. }\end{array}$ & Likert $1-5$ & \\
\hline & $\begin{array}{l}\text { CON3: Website of the beauty salon }(\mathrm{X}) \text { makes it easy to find other useful } \\
\text { links. }\end{array}$ & Likert $1-5$ & \\
\hline \multirow{3}{*}{$\begin{array}{l}\text { Accessibility } \\
\quad \text { (ACC) }\end{array}$} & $\begin{array}{l}\text { ACC1: Website of the beauty salon }(\mathrm{X}) \text { responds to customer requests } \\
\text { quickly. }\end{array}$ & Likert $1-5$ & \multirow{3}{*}{$\begin{array}{l}\text { Kaynama \& Black (2000), } \\
\text { Yang et al. (2005). }\end{array}$} \\
\hline & ACC2: Website of the beauty salon (X) loads quickly. & Likert $1-5$ & \\
\hline & ACC3: Website of the beauty salon (X) is always available for transactions. & Likert 1-5 & \\
\hline \multirow{3}{*}{ Privacy (PRI) } & PRI1: Online transactions are always protected. & Likert $1-5$ & \multirow{3}{*}{$\begin{array}{l}\text { Aladwani \& Palvia (2002), } \\
\text { Kim \& Lee (2004), Ho \& } \\
\text { Lee (2007), Chaiprasit } \\
(2011)\end{array}$} \\
\hline & PRI2: The privacy policy of the website is clear. & Likert $1-5$ & \\
\hline & PRI3: Personal information of customers is always kept confidential. & Likert $1-5$ & \\
\hline \multirow{3}{*}{$\begin{array}{l}\text { Personalization } \\
\text { (PER) }\end{array}$} & PER1: Website of the beauty salon $(\mathrm{X})$ meets customers' special requirements. & Likert $1-5$ & \multirow{3}{*}{$\begin{array}{l}\text { Kaynama \& Black (2000), } \\
\text { Yang \& Jun (2002), Ho \& } \\
\text { Lee }(2007) .\end{array}$} \\
\hline & $\begin{array}{l}\text { PER2: Website of the beauty salon }(\mathrm{X}) \text { can save customer information search } \\
\text { history. }\end{array}$ & Likert $1-5$ & \\
\hline & $\begin{array}{l}\text { PER3: Customers can save the previous search information on the salon's (X) } \\
\text { website. }\end{array}$ & Likert $1-5$ & \\
\hline \multirow{3}{*}{ Innovation (INN) } & $\begin{array}{l}\text { INN1: Website of the beauty salon (X) always keeps up-to-date with new } \\
\text { functions. }\end{array}$ & Likert $1-5$ & \multirow{3}{*}{$\begin{array}{l}\text { Yoo \& Donthu, (2000), } \\
\text { Loiacono et al. (2002), } \\
\text { Madu \& Madu, (2002). }\end{array}$} \\
\hline & INN2: Website of the beauty salon (X) offers innovative products and services. & Likert $1-5$ & \\
\hline & INN3: Website of the beauty salon (X) always leads the newest technologies. & Likert $1-5$ & \\
\hline \multirow{6}{*}{$\begin{array}{l}\text { Brand impression } \\
\qquad(\mathrm{BI})\end{array}$} & BI1: I can clearly remember the beauty salon (X)'s logo and slogan. & Likert $1-5$ & \multirow{6}{*}{$\begin{array}{l}\text { Dobni \& Zinkhan (1990), } \\
\text { Keller (1993), } \\
\text { Yoo (2000), Roy \& } \\
\text { Banerjee (2008). }\end{array}$} \\
\hline & BI2: I have a good impression of the beauty salon (X)'s brand name. & Likert $1-5$ & \\
\hline & BI3: Beauty salon $(\mathrm{X})$ is a reputable brand in my mind. & Likert $1-5$ & \\
\hline & BI4: Beauty salon $(\mathrm{X})$ has the best service quality. & Likert $1-5$ & \\
\hline & BI5: Beauty salon $(\mathrm{X})$ is a brand with modern technologies. & Likert $1-5$ & \\
\hline & $\begin{array}{l}\text { BI6: I always think of the beauty salon (X) first when I have a demand for } \\
\text { beauty services. }\end{array}$ & Likert $1-5$ & \\
\hline \multirow{6}{*}{$\begin{array}{l}\text { Perceived quality } \\
\quad \text { (PQ) }\end{array}$} & PQ1: Beauty salon $(\mathrm{X})$ offers a wide range of services. & Likert $1-5$ & \multirow{6}{*}{$\begin{array}{l}\text { Zeithaml (1988), Dodds } \\
\text { (1991), Yoo et al. (2000), } \\
\text { Nguyen et al. (2011) }\end{array}$} \\
\hline & PQ2: The service quality of the beauty salon $(\mathrm{X})$ is always guaranteed. & Likert $1-5$ & \\
\hline & PQ3: Beauty salon (X) always keeps its commitments with customers. & Likert $1-5$ & \\
\hline & $\begin{array}{l}\text { PQ4: Beauty salon }(\mathrm{X}) \text { is a reliable place for customers who have beauty } \\
\text { service needs. }\end{array}$ & Likert $1-5$ & \\
\hline & PQ5: Beauty salon $(\mathrm{X})$ has good customer service. & Likert $1-5$ & \\
\hline & PQ6: I fully trust in the service quality of the beauty salon (X). & Likert $1-5$ & \\
\hline \multirow{6}{*}{ Brand loyalty (BL) } & BL: Beauty salon $(\mathrm{X})$ is always my first choice. & Likert 1-5 & \multirow{6}{*}{$\begin{array}{l}\text { Deighton et al. (1994), } \\
\text { Aaker, (1991), Nguyen et } \\
\text { al. (2011). }\end{array}$} \\
\hline & $\begin{array}{l}\text { BL2: I would recommend the beauty salon }(\mathrm{X}) \text { to my relatives, friends, and } \\
\text { community. }\end{array}$ & Likert $1-5$ & \\
\hline & BL3: I will continue to use the beauty salon (X)'s services. & Likert $1-5$ & \\
\hline & BL4: I am a loyal customer of beauty salon (X). & Likert $1-5$ & \\
\hline & BL5: Despite the change in the service fee, I chose the beauty salon (X). & Likert $1-5$ & \\
\hline & BL6: I always follow the beauty salon (X)'s activities. & Likert $1-5$ & \\
\hline
\end{tabular}

$\mathbf{H}_{3}$ : Brand impression positively influences the perceived quality of customers towards beauty salons.

The relationship between brand impression and brand loyalty

Brand impression expresses customers' thoughts and feelings about a brand (Roy \& Banerjee, 2008). Brand loyalty indicates the decision to buy products/services and keeps customers from switching to competitors' brands (Yoo, 2000). Several studies have shown that brand loyalty is influenced by the brand impression of customers (Yoo, 2000; Roy \& Banerjee, 2008). Therefore, the H4 hypothesis is suggested:

H4: Brand impression positively impacts brand loyalty to beauty salons.

The relationship between perceived quality and brand loyalty

According to Garretson \& Clow (1999), perceived quality has a positive impact on customers' purchase intentions and enhances their brand loyalty. Kan (2002) argued that the higher the perceived quality, the higher the evaluation of customers towards a product/service. In addition to this, Chi et al. (2009) have proven that brand loyalty depends on the perceived quality of customers. Thus, the following hypothesis is proposed. 
Hs: Perceived quality has a positive impact on the brand loyalty of customers towards beauty salons.

Based on the literature review and research hypotheses, two group discussions (qualitative research) were held with 16 customers ( 8 customers per group) who regularly visit the website and use salon services. The main objective of the discussion was to identify appropriate scales for the research model. The proposed research model is given in Fig. 1.

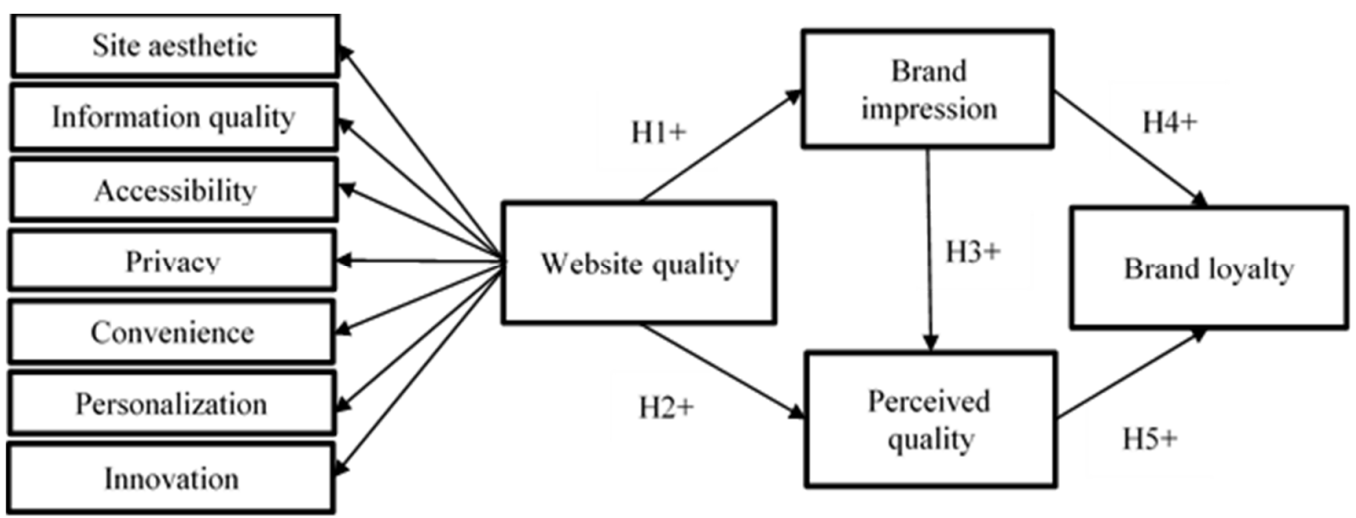

Fig. 1. Proposed research model

\section{Research Methodology}

\subsection{Analytical methods}

In this study, quantitative analytical methods used include the reliability test of the scales by Cronbach's Alpha, exploratory factor analysis (EFA), confirmatory factor analysis (CFA), and structural equation modeling (SEM). These analytical methods are performed in the following order. Step 1: Test the reliability of all scales by Cronbach's Alpha; Step 2: Apply the exploratory factor analysis (EFA) to assess the convergent and discriminant validity of the scales; Step 3: Use the confirmatory factor analysis (CFA) to evaluate the suitability of the data with the market; and Step 4: Use the structural equation modeling (SEM) to test the research hypotheses.

\subsection{Data collection method}

To apply the SEM method, the study requires a large sample size because it is based on the sampling distribution theory (Raykov and Widaman, 1995). To reach the reliability of SEM, the sample size between 100 and 200 is satisfactory (Hoyle, 1995). However, the sample size should be larger than 200 for higher reliability (Hoelter, 1983). The study used quota sampling based on demographic criteria (gender, age, income) and the consumption level of salon services to collect the data. The survey was concentrated in major cities in Vietnam, including Hanoi City, Danang City, Ho Chi Minh City, and Can Tho City. After data screening, the sample size was 300 observations. Thus, the sample size met the requirements, ensuring reliability for the hypothesis test. Demographic characteristics of respondents are described in Table 2.

Table 2

Respondents' demographic characteristics

\begin{tabular}{|c|c|c|}
\hline Characteristic & Frequency & Percentage $(\%)$ \\
\hline 1. Gender & $\mathbf{N}=\mathbf{3 0 0}$ & 100.00 \\
\hline Male & 58 & 19.33 \\
\hline Female & 242 & 80.67 \\
\hline 2. Age & $\mathbf{N}=\mathbf{3 0 0}$ & 100.00 \\
\hline $18-35$ & 54 & 18.00 \\
\hline $36-45$ & 88 & 29.33 \\
\hline $46-60$ & 98 & 32.67 \\
\hline Above 60 & 60 & 20.00 \\
\hline 3. Income (VND) & $\mathbf{N}=\mathbf{3 0 0}$ & 100.00 \\
\hline 6.000 .000 - less than 9.000 .000 & 35 & 11.67 \\
\hline 9.000 .000 - less than 12.000 .000 & 68 & 22.67 \\
\hline 12.000 .000 - less than 15.000 .000 & 92 & 30.66 \\
\hline 15.000 .000 and above & 105 & 35.00 \\
\hline
\end{tabular}




\section{Research Results And Discussions}

\subsection{Test reliability of the scales}

\section{Cronbach's Alpha test}

The Cronbach's Alpha coefficient is used to assess the reliability of the scales and check the level of internal correlation among variables in the scale. According to the result in Table 3, the scales are reliable with Cronbach's alpha values greater than 0.6 (Nunnally, 1978; Peterson, 1994), the smallest value is the Information quality scale (0.711) and the highest value is the Brand loyalty scale (0.93). Besides, the corrected item-total correlation values of variables are all greater than 0.3 (minimum is 0.461 ), so no variable is excluded from the research model (Slater, 1995; Hair et al., 2006).

Table 3

Cronbach's Alpha test result

\begin{tabular}{ccccc}
\hline No. & Scale & Number of variables & Cronbach's Alpha & Minimum corrected item-total correlation \\
\hline 1 & Site aesthetic & 3 & 0.793 & 0.575 \\
2 & Information quality & 3 & 0.711 & 0.507 \\
3 & Accessibility & 3 & 0.721 & 0.504 \\
4 & Privacy & 3 & 0.798 & 0.605 \\
5 & Convenience & 3 & 0.715 & 0.461 \\
6 & Personalization & 3 & 0.868 & 0.702 \\
7 & Innovation & 3 & 0.737 & 0.517 \\
8 & Brand impression & 6 & 0.902 & 0.650 \\
9 & Perceived quality & 6 & 0.882 & 0.628 \\
\hline 10 & Brand loyalty & 6 & 0.903 & 0.678 \\
\hline
\end{tabular}

\section{Exploratory factor analysis (EFA)}

Based on Table 4, the test achieved the following results: (1) Reliability of observed variables is satisfactory (Factor loading $>0.5)$; (2) Appropriateness of the model is guaranteed $(0.5<\mathrm{KMO}=0.793<1.0)$; (3) Bartlett's test of correlation among observed variables is statistically significant (Sig. $=0.00<0.05$ ). Cumulative percentage of variance $=70.5 \%$, higher than 50\% (Anderson \&Gerbing, 1988; Hair et al., 1998). This shows that the observed variables included in the model reach a high explanatory level. Therefore, 7 factors are created from 21 observed variables and there is no disturbance of variables between factors, so the factor names remain.

Table 4

Exploratory factor analysis (EFA) result

\begin{tabular}{|c|c|c|c|c|c|c|c|c|}
\hline \multirow[t]{2}{*}{ Scale } & \multirow[t]{2}{*}{ Sign } & \multicolumn{7}{|c|}{ Factor } \\
\hline & & $\mathrm{F} 1$ & $\mathrm{~F} 2$ & F3 & F4 & F5 & F6 & F7 \\
\hline \multirow[t]{3}{*}{ Personalization } & PER2 & 0.911 & & & & & & \\
\hline & PER3 & 0.862 & & & & & & \\
\hline & PER1 & 0.723 & & & & & & \\
\hline \multirow[t]{3}{*}{ Privacy } & PRI3 & & 0.824 & & & & & \\
\hline & PRI1 & & 0.766 & & & & & \\
\hline & PRI2 & & 0.682 & & & & & \\
\hline \multirow[t]{3}{*}{ Site aesthetic } & SA2 & & & 0.876 & & & & \\
\hline & SA1 & & & 0.786 & & & & \\
\hline & SA3 & & & 0.604 & & & & \\
\hline \multirow{3}{*}{$\begin{array}{l}\text { Information qual- } \\
\text { ity }\end{array}$} & IQ2 & & & & 0.855 & & & \\
\hline & IQ1 & & & & 0.574 & & & \\
\hline & IQ3 & & & & 0.514 & & & \\
\hline \multirow[t]{3}{*}{ Innovation } & INN2 & & & & & 0.869 & & \\
\hline & INN3 & & & & & 0.609 & & \\
\hline & INN1 & & & & & 0.583 & & \\
\hline \multirow[t]{3}{*}{ Convenience } & CON2 & & & & & & 0.845 & \\
\hline & CON1 & & & & & & 0.585 & \\
\hline & CON3 & & & & & & 0.553 & \\
\hline \multirow[t]{3}{*}{ Accessibility } & ACC2 & & & & & & & 0.795 \\
\hline & $\mathrm{ACC} 1$ & & & & & & & 0.627 \\
\hline & ACC3 & & & & & & & 0.583 \\
\hline
\end{tabular}


Next, the Brand impression scale has a value of $\mathrm{KMO}=0.898 \geq 0.5$ and Sig. $=0.00<0.05$ so the data is suitable for factor analysis. One factor is extracted with a total variance extracted $=67.42 \%(>50 \%)$, this means that the Brand impression factor explains $67.42 \%$ of the data variability. Similarly, the Perceived quality scale has a KMO $=0.887 \geq 0.5$ and Sig. $=0.00<$ 0.05 , the data is suitable for factor analysis. One factor is extracted with a total variance extracted $=63 \%(>50 \%)$, meaning that the Perceived quality factor explains $63 \%$ of the variability. Finally, the Brand loyalty scale has a KMO value of $0.903 \geq$ 0.5 and Sig. $=0.00<0.05$, the data is suitable for factor analysis. One factor is extracted with a total variance extracted $=$ $67.7 \%$ ( $>50 \%$ ) which means the Brand loyalty factor explains $67.7 \%$ of the variability.

\section{Confirmatory factor analysis (CFA)}

After the EFA stage, 10 scales are added for the confirmatory factor analysis (CFA). The CFA result shows that the coefficient are guaranteed as follows: Chi-square $/ \mathrm{df}=1.712<2$ with $\mathrm{P}=0.000 \leq 0.05$; TLI $=0.914$ and CFI $=0.924$, both are greater than $0.9 ; \mathrm{RMSEA}=0.049<0.08$. This proves the model is consistent with market data (Bentler \& Bonett, 1980; Carmines \& McIver, 1981). The standardized regression weights of the scales are $>0.5$ and the unstandardized regression weights are statistically significant, so the convergent validity is achieved. Besides, the correlation coefficient of all factors is less than 1 with the standard deviation $<0.05$. Therefore, the model reaches discriminant validity.

Table 5

Result of composite reliability and average variance extracted

\begin{tabular}{cccc}
\hline Factor & Number of variables & Composite reliability $\left(\mathbf{P}_{\mathbf{c}}\right)$ & Average variance extracted $\left(\mathbf{P}_{\mathbf{v c})}\right.$ \\
\hline Site aesthetic & 3 & 0.80 & 0.58 \\
Information quality & 3 & 0.70 & 0.44 \\
Accessibility & 3 & 0.73 & 0.48 \\
Privacy & 3 & 0.80 & 0.57 \\
Convenience & 3 & 0.73 & 0.48 \\
\hline Personalization & 3 & 0.87 & 0.69 \\
Innovation & 3 & 0.74 & 0.49 \\
Brand impression & 6 & 0.90 & 0.61 \\
Perceived quality & 6 & 0.89 & 0.56 \\
\hline Brand loyalty & 6 & 0.90 & 0.60 \\
\hline
\end{tabular}

Source: Survey data, 2020

The result of composite reliability $(\mathrm{Pc})$ and average variance extracted $(\mathrm{Pvc})$ presented in Table 5 shows that the value of Pc meets the requirement, but the Pvc value of 4 scales (information quality, accessibility, convenience, and innovation) are slightly low $(<0.5)$. However, the Pvc can be 0.4 or higher provided that the Pc is greater than 0.6 (Fornell \& Larcker, 1981). Thus, all the scales in the model achieve reliability and they are used for the next SEM stage.

\subsection{Test the relationship between factors in the research model}

Structural equation modeling (SEM) is used to test the research hypotheses. The analytical result is presented in Table 6.

Table 6

Test result of relationships among factors

\begin{tabular}{|c|c|c|c|c|}
\hline Relationship & $\begin{array}{c}\text { Unstandardized regres- } \\
\text { sion weights }\end{array}$ & $\begin{array}{c}\text { Standardized regres- } \\
\text { sion weights }\end{array}$ & P-value & Hypothesis \\
\hline $\mathrm{BI} \leftarrow \mathrm{WEBQUAL}$ & 0.509 & 0.292 & $* * *$ & H1: accepted \\
\hline $\mathrm{PQ} \leftarrow \mathrm{WEBQUAL}$ & 0.302 & 0.192 & $* * *$ & H2: accepted \\
\hline $\mathrm{PQ} \leftarrow \mathrm{BI}$ & 0.765 & 0.847 & $* * *$ & H3: accepted \\
\hline $\mathrm{BL} \leftarrow \mathrm{BI}$ & 0.383 & 0.463 & $* * *$ & H4: accepted \\
\hline $\mathrm{BL} \leftarrow \mathrm{PQ}$ & 0.404 & 0.441 & $* * *$ & H5: accepted \\
\hline
\end{tabular}

Table 6 suggests that hypotheses H1, H2, H3, H4, and H5 are accepted at a 99\% confidence interval. The relationships between the factors are explained as follows:

Hypothesis H1: Website quality positively influences customers' brand impressions on beauty salons. The estimated result in table 6 shows that website quality has a positive impact on brand impression with a standardized coefficient of 0.292 and $\mathrm{p}=$ 0.000. This finding is consistent with studies proposed by Everard \& Galletta (2005), Braddy et al. (2008). This means that the characteristics of a website such as design style, information quality, security, innovation, etc. contribute to improving customers' impression on the beauty salons' website. The better the salons' website quality, the higher the brand impression in the minds of customers, thus promoting positive behavioral intentions. 
Hypothesis H2: Website quality positively affects the perceived quality of customers to beauty salons. This hypothesis is accepted with the standardized coefficients $=0.192$ and the significance level $p=0.000$. It shows the positive relationship between website quality and customer perceived quality for beauty salons. The research result is consistent with studies by Ahn et al. (2004), Hsu et al. (2007). Good reviews from customers of the website positively affect their perceived quality. Therefore, to improve the perceived quality and intention to use the services of customers, beauty salons should regularly upgrade the website quality.

Hypothesis H3: Brand impression has a positive impact on the perceived quality of customers to beauty salons. The analytical result achieves a standardized coefficient $=0.847$ and the significance level $p=0.000$. With a high standardized coefficient, this shows the strong impact of the brand impression on the perceived quality of customers on beauty salons. The result is similar to the findings of Szybillo and Jacoby (1974), Shimp \& Bearden (1982), Rao \& Monroe (1989). If customers always remind of the beauty salon's brand name, have a good impression of it, and trust in the service quality, their perceived quality will be enhanced.

Hypothesis H4: Brand impression positively affects the brand loyalty of customers to beauty salons. The result in Table 6 indicates that brand impression positively affects brand loyalty through a standardized coefficient of 0.463 and a significance level of $\mathrm{p}=0.000$. This finding is consistent with some studies proposed by Yoo (2000), Roy \& Banerjee (2008). When the beauty salon's website creates a good brand impression in customers' minds, it may strengthen the salon's brand name in the market and improve its competitiveness. A positive brand impression helps the administrator build a favorable marketing strategy to effectively reach customers, enhance purchase intention, and build customer loyalty.

Hypothesis H5: Quality perceived positively influences customer loyalty to beauty salons. The result confirms that there is a positive relationship between perceived quality and brand loyalty of customers for beauty salons, with a standardized coefficient of 0.441 and a significance level $p=0.000$. It can be implied that if customers feel the variety of services, the quality assurance, the strict commitment from the beauty salon, they will pay more attention to the salon, tend to choose the salon, and recommend it for relatives, friends, and community. This also means that customer loyalty will be enhanced. The research result is similar to studies by Garretson \& Clow (1999), Kan (2002), Chi et al. (2009).

\section{Conclusion and Implications}

The study has pointed out relationships among website quality, brand impression, perceived quality, and brand loyalty of customers to beauty salons in Vietnam. The results have shown that the factors in the research model are closely related to each other. Website quality has a positive impact on customers' brand impressions and perceived quality towards beauty salons. Next, brand impression positively impacts the perceived quality of customers to beauty salons. Also, brand impression and perceived quality of customers positively affects their brand loyalty to beauty salons. Based on these findings, several administrative implications are proposed to enhance the role of website quality in customers' brand loyalty as follows: Firstly: improve the support and customer care function via the website. Secondly, proactively upgrade new technologies and increase the security level for online transactions. Thirdly, regularly update information and upgrade the website interface. Fourthly, invest in professional services and update the knowledge on new technologies for the web care department.

\section{References}

Aaker, D. A. (1991). Managing brand equity: Capitalizing on the value of a brand name. New York: The Free Press.

Ahn, T., Ryu, S., \& Han, I. (2004). The impact of the online and offline features on the user acceptance of Internet shopping malls. Electronic Commerce research and applications, 3(4), 405-420.

Aladwani, A. M., \& Palvia, P. C. (2002). Developing and validating an instrument for measuring user-perceived web quality. Information \& Management, 39(6), 467-476.

Anderson, J. C., \& Gerbing, D. W. (1988). Structural equation modeling in practice: A review and recommended two-step approach. Psychological Bulletin, 103(3), 411-423.

Baggozi, R. P., \& Dholakia, U. M. (2006). Antecedents and purchase consequences of customer participation in small group brand communities. International Journal of Research in Marketing, 23(1), 45-61.

Bagozzi, R. P., Gopinath, M., \& Nyer, P. U. (1999). The role of emotions in marketing. Journal of the Academy of Marketing Science, 27(2), 184-206.

Baldinger, A. L., \& Rubinson, J. (1996). Brand loyalty: the link between attitude and behavior. Journal of Advertising reSearch, 36(6), 22-35.

Bentler, P. M., \& Bonett, D. G. (1980). Significance tests and goodness of fit in the analysis of covariance structures. Psychological Bulletin, 88(3), 588-606.

Braddy, P. W., Meade, A. W., \& Kroustalis, C. M. (2008). Online recruiting: The effects of organizational familiarity, website usability, and website attractiveness on viewers' impressions of organizations. Computers in Human Behavior, 24(6), 2992-3001.

Brújula, S. C., \& Calvo, J. J. C. (1997). Las estrategias de captación y retención de clientes y la lealtad: un análisis de segmentación. Revista española de investigación de marketing, 1(1), 55-72.

Carlson, J., Sinnappan, S., \& Voola, R. (2003). Application of the WebQual instrument to three Australian B2C websites: An exploratory investigation. In Australian and New Zealand Marketing Academy Conference (ANZMAC). 
Carmines, E. G., \& Mclver, J. P. (1981). Analyzing Models with Unobserved Variables. In G. W. Bohrnstedt, \& E. F. Borgatta (Eds.). Social Measurement: Current Issues (pp. 65-115). Beverly Hills, CA: Sage.

Collins, G. R., \& Cobanoglu, C. (2013). Hospitality information technology: Learning how to use it. (8 ${ }^{\text {th }}$ ed.). Dubuque, IA: Kendall/Hunt Publishing Co.

Cox, J., \& Dale, B. G. (2001). Service quality and e-commerce: an exploratory analysis. Managing Service Quality: An International Journal, 11(2), 121-131.

Chaiprasit, K., Jariangprasert, N., Chomphunut, A., Naparat, D., \& Jaturapataraporn, J. (2011). Tourist expectations toward travel and tourism websites in Thailand. International Business \& Economics Research Journal (IBER), 10(3), 41-50.

Chaudhuri, A., \& Holbrook, M. B. (2001). The chain of effects from brand trust and brand affect to brand performance: the role of brand loyalty. Journal of Marketing, 65(2), 81-93.

Chi, H. K., Yeh, H. R., \& Yang, Y. T. (2009). The impact of brand awareness on consumer purchase intention: The mediating effect of perceived quality and brand loyalty. Journal of International Management Studies, 4(1), 135-144.

Dawar, N. (1996). Extensions of broad brands: The role of retrieval in evaluations of fit. Journal of Consumer Psychology, 5(2), 189-207.

Deighton, J., Henderson, C.M., Neslin, S.A. (1994), The effect of advertising on brand switching and repeat purchasing. Journal of Marketing Research, 31, 28-43.

Dobni, D., \& Zinkhan, G. M. (1990). In search of brand image: A foundation analysis. In M. E. Goldberg, G. Gorn, \& R. W. Pollay (Eds.). Advances in Consumer Research (Vol. 17, pp. 110-119). Provo, UT: Association for Consumer Research.

Dodds, W. B., Monroe, K. B., \& Grewal, D. (1991). Effects of price, brand, and store information on buyers' product evaluations. Journal of Marketing Research, 28(3), 307-319.

Everard, A., \& Galletta, D. F. (2005). How presentation flaws affect perceived site quality, trust, and intention to purchase from an online store. Journal of Management Information Systems, 22(3), 56-95.

Fornell, C., \& Larcker, D. F. (1981). Evaluating structural equation models with unobservable variables and measurement error. Journal of Marketing Research, 18(1), 39-50.

Garretson, J. A., \& Clow, K. E. (1999). The influence of coupon face value on service quality expectations, risk perceptions, and purchase intentions in the dental industry. Journal of Services Marketing, 13(1), 59-72.

Geissler, G. L. (2001). Building customer relationships online: the web site designers' perspective. Journal of Consumer Marketing, 18(6), 488-502.

Hair, J. F., Black, W. C., Babin, B. J., Anderson, R. E., \& Tatham, R. L. (2006). Multivariate Data Analysis (6 $6^{\text {th }}$ ed.). New Jersey: Prentice-Hall.

Hair, J. F., Tatham, R. L., Anderson, R. E., \& Black, W. C. (1998). Multivariate Data Analysis (5 ${ }^{\text {th }}$ ed.). New Jersey: PrenticeHall.

Ho, C. I., \& Lee, Y. L. (2007). The development of an e-travel service quality scale. Tourism Management, $28(6), 1434-1449$.

Hoelter, J. W. (1983). The analysis of covariance structures: Goodness-of-fit indices. Sociological Methods \& Research, 11(3), 325-344.

Holbrook, M. B., \& Corfman, K. P. (1985). Quality and value in the consumption experience: Phaedrus rides again. Perceived Quality, 31(2), 31-57.

Hoyle, R. H. (1995). The structural equation modeling approach: Basic concepts and fundamental issues. In R. H. Hoyle (Ed.). Structural equation modeling: Concepts, issues, and applications (p. 1-15). Oaks, CA: Sage Publications, Inc.

Hsieh, M. H., Pan, S. L., \& Setiono, R. (2004). Product-, corporate-, and country-image dimensions and purchase behavior: A multicountry analysis. Journal of the Academy of Marketing Science, 32(3), 251-270.

Hsu, H. C., Lai, C. S., \& Chen, C. H. (2007). Extrinsic cue of warranty by selling through a reputable website. Journal of Advertising Research, 47(2), 158-164.

Jeon, M. M., \& Jeong, M. (2017). Customers' perceived website service quality and its effects on e-loyalty. International Journal of Contemporary Hospitality Management, 29(1), 438-457.

Jeong, M., \& Lambert, C. U. (2001). Adaptation of an information quality framework to measure customers' behavioral intentions to use lodging Web sites. International Journal of Hospitality Management, 20(2), 129-146.

Kan, S. H. (2002). Metrics and models in software quality engineering. Boston: Addison-Wesley Longman Publishing Co., Inc.

Karimov, F. P., Brengman, M., \& Van Hove, L. (2011). The effect of website design dimensions on initial trust: A synthesis of the empirical literature. Journal of Electronic Commerce Research, 12(4), 272-301.

Kaynama, S. A., \& Black, C. I. (2000). A proposal to assess the service quality of online travel agencies: an exploratory study. Journal of Professional Services Marketing, 21(1), 63-88.

Keller, K. L. (1993). Conceptualizing, measuring, and managing customer-based brand equity. Journal of Marketing, 57(1), $1-22$.

Kim, H. R. (2005). Developing an index of online customer satisfaction. Journal of Financial Services Marketing, 10(1), 4964.

Kim, J., Morris, J. D., \& Swait, J. (2008). Antecedents of true brand loyalty. Journal of Advertising, 37(2), 99-117.

Kim, W. G., \& Lee, H. Y. (2005). Comparison of web service quality between online travel agencies and online travel suppliers. Journal of Travel \& Tourism Marketing, 17(2-3), 105-116.

Kim, W., and Lee, H.Y. (2004). Comparison of web service quality between online travel agencies and online travel suppliers. Journal of Travel and Tourism Marketing, 17(2-3), 105-116. 
Kotler, P., \& Armstrong, G. (2010). Principles of Marketing (13 ${ }^{\text {th }}$ ed.). Upper Saddle River, NJ: Pearson education.

Li, W. Z., \& Jiao, A. Y. (2008). The impact of website and offline equality on relationship quality: An empirical Study on eretailing. In 2008 4th International Conference on Wireless Communications, Networking and Mobile Computing (pp. 15). IEEE.

Loiacono, E., Watson, R., \& Goodhue, D. (2002). WebQual ${ }^{\mathrm{TM}}$ : A measure of website quality. In Evans, K., Scheer, L. (Eds.). Marketing educators' conference: Marketing Theory and Applications. 13, 432-437.

Madu, C. N., \& Madu, A. A. (2002). Dimensions of e-quality. International Journal of Quality \& Reliability Management, 19(3), 246-258.

Mohamed, I., \& Moradi, L. (2011). A model of e-tourism satisfaction factors for foreign tourists. Australian Journal of Basic and Applied Sciences, 5(12), 877-883.

Moon, J. W., \& Kim, Y. G. (2001). Extending the TAM for a World-Wide-Web context. Information \& Management, 38(4), 217-230.

Newman, W. G. (1975). Possible etiologic factors in external root resorption. American Journal of Orthodontics, 67(5), 522539.

Nunnally, J. C. (1978). Psychometric Theory. New York: McGraw- Hill.

Nusair, K. K., \& Kandampully, J. (2008). The antecedents of customer satisfaction with online travel services: a conceptual model. European Business Review, 20(1), 4-19.

Nguyen, T. D., Barrett, N. J., \& Miller, K. E. (2011). Brand loyalty in emerging markets. Marketing Intelligence \& Planning, 29(3), 222-232.

Oliver, R. L. (1999). Whence consumer loyalty?. Journal of Marketing, 63(4_suppl1), 33-44.

Park, C. W., Jaworski, B. J., \& MacInnis, D. J. (1986). Strategic brand concept-image management. Journal of Marketing, 50(4), 135-145.

Peterson, R. A. (1994). A meta-analysis of Cronbach's coefficient alpha. Journal of Consumer Research, 21(2), $381-391$.

Rao, A. R., \& Monroe, K. B. (1989). The effect of price, brand name, and store name on buyers' perceptions of product quality: An integrative review. Journal of Marketing Research, 26(3), 351-357.

Raykov, T., \& Widaman, K. F. (1995). Issues in applied structural equation modeling research. Structural Equation Modeling: A Multidisciplinary Journal, 2(4), 289-318.

Richardson, P. S., Dick, A. S., \& Jain, A. K. (1994). Extrinsic and intrinsic cue effects on perceptions of store brand quality. Journal of Marketing, 58(4), 28-36.

Roy, D., \& Banerjee, S. (2007). CARE-ing strategy for integration of brand identity with brand image. International Journal of Commerce and Management, 17(1/2), 140-148.

Shimp, T. A., \& Bearden, W. O. (1982). Warranty and other extrinsic cue effects on consumers' risk perceptions. Journal of Consumer Research, 9(1), 38-46.

Slater, S. F. (1995). Issues in conducting marketing strategy research. Journal of strategic Marketing, 3(4), $257-270$.

Sutikno, B. (2011). Does Consumers' Brand Identification Matter: The Mediating Roles of Brand Loyalty. International Journal of Interdisciplinary Social Sciences, 6(3), 1833-1882.

Szybillo, G. J., \& Jacoby, J. (1974). Intrinsic versus extrinsic cues as determinants of perceived product quality. Journal of Applied Psychology, 59(1), 74-78.

Wang, L., Law, R., Guillet, B. D., Hung, K., \& Fong, D. K. C. (2015). Impact of hotel website quality on online booking intentions: eTrust as a mediator. International Journal of Hospitality Management, 47, 108-115.

Winter, S. J., Saunders, C., \& Hart, P. (2003). Electronic window dressing: Impression management with websites. European Journal of Information Systems, 12(4), 309-322.

Yang, Z., \& Jun, M. (2002). Consumer perception of e-service quality: from internet purchaser and non-purchaser perspectives. Journal of Business Strategies, 19(1), 19-41.

Yang, Z., Cai, S., Zhou, Z., \& Zhou, N. (2005). Development and validation of an instrument to measure user perceived service quality of information presenting web portals. Information \& management, 42(4), 575-589.

Yoo, B., Donthu, N., \& Lee, S. (2000). An examination of selected marketing mix elements and brand equity. Journal of the academy of marketing science, 28(2), 195-211.

Zeithaml, V. A. (1988). Consumer perceptions of price, quality, and value: A means-end model and synthesis of evidence. Journal of Marketing, 52(3), 2-22. 
(C) 2021 by the authors; licensee Growing Science, Canada. This is an open access article distributed under the terms and conditions of the Creative Commons Attribution (CC-BY) license (http://creativecommons.org/licenses/by/4.0/). 